\title{
Восприятие западноевропейского искусства русскими путешественниками второй половины XVIII века: проблемы историографии
}

\begin{abstract}
Аннотация: в статье рассматривается историография изучения восприятия русскими путешественниками второй половины XVIII века западноевропейского искусства (на примере рапортов пенсионеров Академии художеств) параллельно с обозначением этапов русского искусствознания с середины ХІХ века до наших дней. Дается деление всех русских путешественников второй половины XVIII века на группы по уровню осведомленности в искусстве и сословной принадлежности. Освещаются этапы знакомства с западноевропейским искусством во время путешествия: заочное знакомство дома, формирование художественного сознания, непосредственное восприятие, осмысление, подтверждение или пересмотр знаний с учетом приобретенных впечатлений. Сравнительный анализ искусствоведческих трудов по обозначенной теме и путевых журналов пенсионеров дает представление об изученности вопроса и обозначает направления дальнейших исследований.

Ключевъе слова: Искусствоведение, культура, западноевропейское искусство, восприятие, путешественник, пенсионер, Академия художеств, Европа, Россия, XVIII век.
\end{abstract}

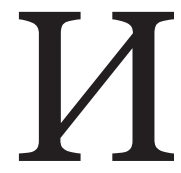

зучение в русском искусствознании проблем восприятия русскими путешественниками западноевропейского искусства во второй половине XVIII века имеет целый спектр особенностей. Первая особенность заключается в неоднородности части русского общества, имеющей отношение к искусству, как по уровню осведомленности в искусстве, так и по художественным вкусам и пристрастиям, определяемым профессиональной и сословной принадлежностью. По этому принципу всех русских путешественников второй половины XVIII века (а круг русских людей, имевших возможность в этот период выехать за границу, был очень невелик) можно разделить на две основные группы: пенсионеры Академии художеств и русское образованное дворянство. Вторая особенность состоит в необходимости учета общих эстетических представлений в России и в Европе второй половины XVIII века и влияния европейских представлений на русские. Поэтому освещение историографии по заданной теме будет включать в себя обзор исследований по обозначенным аспектам и их вплетение в хронологическом порядке в общую канву искусствоведческих трудов о русских художниках, которые во второй по- ловине XVIII века были отправлены пенсионерами в Европу.

Культурные контакты, как явление двустороннее, рассматривались исследователями с двух точек зрения - деятельность иностранцев в России и русских в Европе. Деятельность иностранцев в России во второй половине XVIII века изучена гораздо больше, чем деятельность русских за рубежом, хотя и здесь сделано немало. Путешествия русских людей за границу в XVIII веке стали предметом осмысления уже современниками. Дневники, записки и путевые журналы предоставляют неисчерпаемый материал для изучения восприятия нашими путешественниками западноевропейского искусства и последующего влияния этого восприятия на изменение художественного сознания в русском обществе.

Путешествия наших соотечественников в Европу нужно рассматривать как явление многоэтапное. Первый этап - это заочное знакомство с европейской художественной культурой у себя дома. Вторым этапом являлось формирование художественного сознания на основании этого знакомства. Далее, путешественник, приезжая в Европу, начинал осваивать следующий этап, на котором представление сменялось непосред- 


\section{Культура и искусство 3(15) • 2013}

ственным восприятием. Вслед за ним шло осмысление увиденного. И как окончательный этап этого явления - либо подтверждение полученных до путешествия знаний, либо их пересмотр и переоценка с учетом приобретенных за рубежом впечатлений. Изучение оценок европейского искусства в русском обществе и изучение развития самого русского искусства XVIII века протекало параллельно с конца XIX века до наших дней.

В течение XVIII века русское искусство претерпело сложную трансформацию - оно преобразовалось из искусства средневекового в искусство Нового времени. В последующем столетии с его новыми задачами в искусстве русское искусство XVIII века было предано забвению. Только в 1840-е годы появляются первые упоминания о русском искусстве прошлого столетия. На рубеже XIX$\mathrm{XX}$ столетий в русском обществе зарождается устойчивый интерес к русскому искусству XVIII века. Это происходит благодаря деятельности художественного объединения «Мир искусства». В одноименном журнале были заново открыты имена и произведения мастеров забытого периода. Работа объединения внесла существенный вклад в становление и развитие отечественного искусствознания. Этому же способствовал выпуск журнала «Старые годы», ежемесячник для любителей искусства и старины». Журнал выходил с 1907 по 1916 год и был посвящен, в значительной степени, творчеству художников XVIII столетия.

Начало XX века ознаменовалось появлением систематизированных трудов по истории русского искусства таких авторов, как И. Э. Грабарь ${ }^{1}$, Д. В. Айналов ${ }^{2}$, К. Верман $^{3}$, В. А. Никольский ${ }^{4}$. Богатый материал, собранный в этих изданиях, был классифицирован по времени, видам и жанрам искусства.

Рассмотрим историю изучения русского искусства с точки зрения творчества тех художников, которые во второй половине XVIII века посылались пенсионерами за границу. Мы будем опираться на исследования творчества пенсионеров, записи которых сохранились и были опубликованы.

${ }^{1}$ Грабарь И. Э. История русского искусства. М., Изд-во И. Кнебеля, 1910-1913.

${ }^{2}$ Айналов Д. В. История русской живописи от XVI до XIX века. СПб., 1909.

${ }^{3}$ Верман К. История всех времен и народов. М., 2000.

${ }^{4}$ Никольский В. А. История русского искусства. М., 1915.
Основательной базой для изучения вопроса пенсионерства явился изданный еще в середине XIX века сборник материалов Академии художеств под редакцией П. Петрова 5 . В нем содержится богатый фактический материал по истории деятельности Академии художеств.

В начале XX века в журнале «Старые годы» публикуется статья А. Трубникова ${ }^{6}$, где автор делает экскурс в историю создания Академии художеств, приводит список первых пенсионеров и воссоздает отношения русских художников с зарубежными мастерами. Также Трубников рассказывает об особенностях отношений между Академией и ее учениками, выехавшими на обучение за границу, откуда четыре раза в год они должны были уведомлять в рапортах Академию о своих занятиях и о том, какие достопримечательности они видели.

Параллельно исследованиям русского искусства становятся актуальными исследования русских путешествий XVIII века. Еще в конце XIX века появились первые публикации на тему дипломатических отношений между Россией и Францией (П. В. Безобразов$^{7}$, В. С. Иконников $\left.{ }^{8}\right)$. В начале XX века тема путешествий рассматривалась уже с исторической точки зрения (А. А. Кизеветтер $^{9}$, С. А. Князьков ${ }^{10}$, П. П. Пекарский $\left.{ }^{11}\right)$.

И, наконец, первым исследованием впечатлений русских путешественников от европейской культуры можно считать работу К. Сивкова ${ }^{12}$, появившуюся в 1914 году. Автор публикует отрывки из путевых журналов, дневников и писем русских дворян, путешествовавших в Европу на протяжении всего XVIII века. Русский путешественник второй половины XVIII века, будучи заочно знаком с европейской культурой, ехал в Европу, чтобы воспринимать, оценивать и осмысливать, в отличие от путешественника

${ }^{5}$ Сборник материалов для истории Императорской СанктПетербургской академии художеств за 100 лет. Под редакцией Петрова П. Н. СПб., 1864-1866.

${ }^{6}$ Трубников A. Пенсионеры академии художеств в XVIII веке. // Старые годы. Июль-сентябрь, 1907.

7 Безобразов П. В. О сношениях России с Францией. М., Университетская типография, 1892.

${ }^{8}$ Иконников В. С. Сношения России с Францией (XVI-XVIII вв.). Исторический очерк. М., 1893.

${ }^{9}$ Кизеветтер А. А. Петр Великий за границей. М., 1910.

${ }^{10}$ Князъков С. А. Петр Великий и его современники за границей. Пг., 1915.

${ }^{11}$ Пекарский П. П. Наука и литература в России при Петре Великом. СПб., 1862.

${ }^{12}$ Сивков К. В. Путешествия русских людей за границу в XVIII веке. СПб., 1914. 


\section{Искусство и искусствознание}

первой половины XVIII столетия, который за границей просто удивлялся иностранным диковинкам.

Все вышеперечисленные труды имеют фактографический характер, их отличительной особенностью является собрание исторических материалов и фактов. Они предоставляют основательную базу для дальнейших исследований в самых разных аспектах.

В 1920-1930-е гг. появляются монографии, посвященные деятельности русских художников второй половины XVIII века. В этих монографиях авторы делают акцент на особенностях художественных приемов и методов, используемых художниками. А также уделяют внимание пенсионерству, которому посвящаются целые разделы. Но тема пенсионерства пока рассматривается только как факт в биографии художника, вопросы восприятия западноевропейского искусства и влияния этого восприятия на деятельность русских художников не затрагиваются. Собранный десятилетием ранее фактический материал предоставил возможности для формирования нового этапа русского искусствознания, во главе которого встал формально-стилистический метод. Для этого метода важно не то, как художник смотрит на мир, а то, какие художественные средства он использует, и как эти средства характеризуют принадлежность к тому или иному стилю, который является порождением мировоззрения и культурных процессов в стране. Примером могут служить исследования С. Ухтомского ${ }^{13}$ и С. Исакова ${ }^{14}$ о Ф. Шубине, В. Згура ${ }^{15}$ и С. Голубева ${ }^{16}$ о В. Баженове, Н. Коваленской ${ }^{17}$ о И. Мартосе.

В это же время выходит большой труд C. Яремича ${ }^{18}$, посвященный русской академической художественной школе в XVIII веке. В нем рассматриваются вопросы создания и формирования Императорской Академии художеств в Петербурге - история основания первого художественного заведения в России, особенности руководства И. И. Шувалова и впоследствии И. И. Бецкого, специфика

${ }_{13}$ Ухтомский С. Федот Иванович Шубин. Л., 1928.

${ }^{14}$ Исаков С. К. Федот Шубин. М., «Искусство», 1938.

${ }^{15}$ Згура В. В. проблемы и памятники, связанные с В.И. Баженовым. Казань., 1928.

${ }^{16}$ Голубев С. Н. Труды и дни архитектора Василия Баженова. М., 1937.

${ }^{17}$ Коваленская Н. Н. Мартос. М.-Л., Искусство, 1938.

18 Яремич С. П. Русская академическая художественная школа в XVIII веке. М.-Л., 1934. художественной и воспитательной систем, а также сотрудничество с иностранными мастерами.

1940-1950-е гг. характеризуются поисками реализма в русском искусстве XVIII века. Исследователи этого периода рассматривали творчество русских художников через призму реализма как высшей точки развития искусства, согласно представлениям обозначенного периода. Примером могут служить исследования А. Ромма ${ }^{19}$ о М. Козловском, А. Савинова ${ }^{20}$ о А. Лосенко, Г. Недошвина ${ }^{21}$ и Г. Жидкова ${ }^{22}$ о Ф. Шубине, М. Алпатова ${ }^{23}$ о И. Мартосе, А. Скворцова ${ }^{24}$ о Ф. Алексееве, А. Федорова-Давыдова ${ }^{25}$ о русском пейзаже и первых представителях этого жанра - Семене Щедрине и Федоре Алексееве. Так же, как и несколькими десятилетиями ранее, авторы рассматривают пенсионерство всего лишь как составляющую в биографии художника. Исключением является работа А. Л. Кагановича ${ }^{26}$ о скульпторе Феодосии Щедрине, поскольку она содержит первую попытку в истории русского искусствознания анализа пенсионерского рапорта.

Вопросы развития русского искусства второй половины XVIII века и влияния западноевропейского искусства на искусство в России в XVIII века освещены в исследовании Н. Молевой и Э. Белютина «Педагогическая система Академии художеств»27. Академия, ориентируясь на европейскую систему обучения, способствовала утверждению в России общеевропейских художественных направлений, и пенсионерские поездки наших художников являлись одним из механизмов внедрения общеевропейских художественных принципов в русскую культуру. А именно, обучение у именитых иностранных

\footnotetext{
19 Ромм А. Г. Михаил Иванович Козловский. 1753-1802 [Жизнь и творчество русского скульптора]. М.-Л., «Искусство», 1945.

${ }^{20}$ Савинов А. Н. Антон Павлович Лосенко. М.-Л., 1948.

${ }^{21}$ Недошвин Г. А. Шубин Федот Иванович. 1740-1805. [Краткий очерк жизни и деятельности]. М.-Л., «Искусство», 1944. ${ }_{22}^{2}$ Жидков Г. В. Образ Шубина. К 140-летию со дня смерти великого русского скульптора. [1805-1945]. М., 1946.

${ }^{23}$ Алпатов М.В. Иван Петрович Мартос. М.-Л., Искусство., 1947.

${ }^{24}$ Скворцов А. Федор Яковлевич Алексеев. М.-Л., «Искусство», 1945.

25 Федоров-Давыдов А. А. Русский пейзаж. XVIII- начало ХІХ века. М., 1953.

${ }^{26}$ Каганович А. Л. Щедрин Феодосий Федорович. 1751-1825. М., «Искусство», 1953.

${ }^{27}$ Молева Н. М., Белютин Э. М. Педагогическая система в Академии художеств XVIII века. М., 1956.
} 


\section{Культура и искусство 3(15) • 2013}

мастеров и знакомство с их художественными методами и приемами, а также обогащение художественной осведомленности путем очного знакомства с европейской культурой.

В 1960-е гг. особенно сильно начинает прослеживаться тенденция к разложению проблематики русского искусства на отдельно взятые аспекты. Например, вопрос пенсионерства начинает звучать по-новому - его изучают не с фактографической точки зрения, а с точки зрения анализа и оценок европейского искусства русскими художниками. Этому немало способствовали публикации в 1960-е гг. в многотомнике «Мастера искусства об искусстве» некоторых сохранившихся отчетов и журналов первых пенсионеров Академии художеств второй половины XVIII века: А. Лосенко, Ф. Шубина, А. Иванова, Ф. Щедрина, М. Козловского, $\Phi$. Алексеева. Опубликованные материалы предоставили широкий простор для изучения художественных предпочтений путешественников, имеющих художественное образование и воспринимающих искусство с профессиональной точки зрения.

Один из самых интересных и разносторонних среди опубликованных журналов - это журнал Лосенко. Несмотря на то, что записи в журнале напоминали скорее перечень увиденных достопримечательностей, нежели анализ увиденного, журнал предоставил многим исследователям возможность выявления художественных вкусов молодого мастера. Первые упоминания о поездках Лосенко в Европу появлялись еще в 1930-1940-е гг. в статьях С. Эрнста ${ }^{28}$ и А. Савинова ${ }^{29}$. Но в этих работах приводились лишь некоторые упоминания о заграничных записях художника и затрагивались только вопросы обучения у иностранных мастеров.

В 1963 году выходит большое исследование А.Л. Кагановича ${ }^{30}$, где полностью публикуется «Журнал» Лосенко. В книге целая глава посвящается пребыванию молодого русского художника в Париже. Каганович детально разбирает записи Лосенко, анализирует их и делает выводы о его предпочтениях. Это дает представление об особенностях его восприятия и осмысления

\footnotetext{
${ }^{28}$ Эрнст С. Р. Лосенко. СПб., 1914.

${ }^{29}$ Савинов А. Н. Антон Павлович Лосенко. М.-Л., 1948.

зо Каганович А. Л. Антон Лосенко и русское искусство XVIII столетия. М., 1963.
}

западноевропейского искусства, что в дальнейшем, по мнению автора, отразилось на его творческой деятельности уже в России.

Опубликованные в многотомнике «Мастера искусства об искусстве» рапорты пенсионеров способствовали появлению новых исследований, раскрывающих вопросы пенсионерства. Творчество Ф. Шубина и его пенсионерскую поездку изучила О. Лазарева $^{31}$. Н. Коваленская ${ }^{32}$ рассмотрела римский журнал М. Козловского и заграничную поездку $\Phi$. Алексеева. Надо отметить, что журнал венецианских впечатлений Алексеева остался почти не изученным, и это предоставляет широкие возможности для современных исследователей.

Кроме того, 1960-е гг. открыли новое направление изучения русской культуры - с точки зрения эстетики. Мощным толчком к подобному исследованию явилась публикация трактатов об искусстве второй половины XVIII века в многотомнике «История эстетики. Памятники мировой эстетической мысли» ${ }^{33}$. Во вступительной статье А. Штамбока присутствует характеристика эстетических представлений в России в XVIII веке и анализ идей, изложенных в этих трактатах. Также автор выделяет несколько этапов развития русской эстетики, пройденных ею во второй половине XVIII века: просветительский классицизм, сентиментализм и просветительский реализм, что соответствовало духу времени предыдущих десятилетий с его поисками реализма в искусстве.

Все вышеупомянутые трактаты в дальнейшем были разобраны в хронологическом порядке и проанализированы Н. Коваленской в работе «Русский классицизм»34. Она рассмотрела трактаты об искусстве уже с другого ракурса - как начало теории изобразительного искусства в России.

1970-1980-е гг. характеризуются появлением монографий, в которых авторы рассматривают творчество художников в контексте культурной среды и художественных направлений, существовавших в определенные исторические периоды. Примером подобных исследований являются работы

\footnotetext{
${ }^{31}$ Лазарева О. П. Русский скульптор Федот Шубин. М., «Искусство», 1965.

32 Коваленская Н. Н. Русский классицизм. Живопись, скульптура, графика. М., «Искусство», 1964.

33 История эстетики. Памятники мировой эстетической мысли. Эстетические учения XVII-XVIII веков. М., 1964. Т. 2. ${ }^{34}$ Коваленская Н. Н. Указ.соч.
} 


\section{Искусство и искусствознание}

Е. Гавриловой о А. Лосенко ${ }^{35}$, Е. Петиновой о Федосе Щедрине ${ }^{36}$, И. Гофман об И. Мартосе $^{37}$, В. Петрова о М. Козловском ${ }^{38}$, М. Андросовой о $Ф$. Алексееве ${ }^{39}$.

В это же время исследователи стали рассматривать русское искусство как составляющую русской культуры. Особенности русской культуры XVIII века были раскрыты в работе Ю. М. Лотмана «История и типология русской культуры» ${ }^{40}$.

1990-е гг. положили начало исследованиям письменных свидетельств путешественников в новом аспекте. Если ранее авторы разбирали оценки европейского искусства отдельно взятого путешественника, которого они рассматривали в контексте художественной среды второй половины XVIII века, теперь методологической особенностью исследований становится сравнительный анализ мнений об искусстве русских путешественников. Например, И. Марисина в своем исследовании «Россия - Франция. Век восемнадцатый» ${ }^{41}$ рассматривает широкий круг русских путешественников, сравнивает цели их путешествий, особенности художественного восприятия и результаты осмысления увиденного. Значительное место в этой работе уделяется критериям восприятия, а также вопросам формирования лексики суждений об искусстве. Автор утверждает, что словарь зрительских суждений формировался параллельно с системой профессиональных оценок.

В более широком диапазоне изучается вопрос осмысления результатов художественных контактов между русскими и ев- ропейцами во второй половине XVIII века О. С. Евангуловой в монографии «Русское художественное сознание XVIII века и искусство европейских школ» ${ }^{42}$. Исследование посвящено изучению влияния основных художественных школ Европы на формирование русской художественной школы и русского художественного сознания. Автор сравнивает суждения об искусстве в теоретических трактатах с оценками и высказываниями пенсионеров Академии художеств.

В 1993 году вышел сборник издаваемой по настоящее время серии «Русское искусство Нового времени». Сборник включает в себя статьи современных авторов о русском искусстве Нового времени. Применительно к заданной теме, статьи из этого сборника отражают все многообразие аспектов, которые выкристаллизовывались в течение более чем столетнего изучения русского искусства XVIII века.

За это время русское искусствознание прошло самые разные этапы. Каждый из этих этапов имел свое значение для возможности появления следующего этапа с его новыми концепциями и методами. Искусствоведческие труды всех обозначенных этапов, выстраиваясь в хронологическом порядке, дают полный обзор достижений в изучении поставленного вопроса, что, в свою очередь, позволяет судить о степени изученности данного вопроса и, в то же время, выявить неизученные пустоты, которые предоставляют возможности для дальнейших исследований.

\section{Список литературы:}

1. Айналов Д. В. История русской живописи от XVI до XIX века. СПб., 1909.

2. Алпатов М.В. Иван Петрович Мартос. М.-Л., Искусство., 1947.

3. Андросова М. И. Федор Алексеев. 1753-1824. Л., 1979.

4. Безобразов П. В. О сношениях России с Францией. М., Университетская типография, 1892.

5. Верман К. История всех времен и народов. М., 2000.

6. Гаврилова Е. И. Антон Павлович Лосенко. Л., 1977.

\footnotetext{
${ }^{35}$ Гаврилова Е. И. Антон Павлович Лосенко. Л., 1977.

${ }^{36}$ Петинова Е. Ф. Федос Щедрин. Л., «Художник РСФСР», 1977.

37 Гофман И. М. Иван Петрович Мартос. Л., Художник РСФСР, 1970.

${ }^{38}$ Петров В. Н. Михаил Иванович Козловский. М., «Искусство», 1977.

${ }^{39}$ Андросова М. И. Федор Алексеев. 1753-1824. Л., 1979.

${ }^{40}$ Лотман. Ю. М. История и типология русской культуры. СПб., 2002.

${ }^{41}$ Марисина И. М. Россия - Франция. Век восемнадцатый. M., 1995.
}

\footnotetext{
42 Евангулова О. С. Русское художественное сознание XVIII века и искусство западноевропейских школ. М., «Памятники исторической мысли», 2007.
} 


\section{Культура и искусство 3(15) • 2013}

7. олубев С. Н. Труды и дни архитектора Василия Баженова. М., 1937.

8. Гофман И. М. Иван Петрович Мартос. Л., Художник РСФСР, 1970.

9. Грабарь И. Э. История русского искусства. М., Изд-во И. Кнебеля, 1910-1913.

10. Евангулова О. С. Русское художественное сознание XVIII века и искусство западноевропейских школ. М., «Памятники исторической мысли», 2007.

11. Жидков Г. В. Образ Шубина. К 140-летию со дня смерти великого русского скульптора. [1805-1945]. М., 1946.

12. Згура В. В. проблемы и памятники, связанные с В.И. Баженовым. Казань., 1928.

13. Иконников В. С. Сношения России с Францией (XVI-XVIII вв.). Исторический очерк. М., 1893.

14. Исаков С. К. Федот Шубин. М., «Искусство», 1938.

15. Каганович А. Л. Антон Лосенко и русское искусство XVIII столетия. М., 1963.

16. Каганович А. Л. Щедрин Феодосий Федорович. 1751-1825. М., «Искусство», 1953.

17. К Кизеветтер А. А. Петр Великий за границей. М., 1910.

18. Князьков С. А. Петр Великий и его современники за границей. Пг., 1915.

19. Коваленская Н. Н. Мартос. М.-Л., Искусство, 1938.

20. Коваленская Н. Н. Русский классицизм. Живопись, скульптура, графика. М., «Искусство», 1964.

21. Лазарева О. П. Русский скульптор Федот Шубин. М., «Искусство», 1965.

22. Лотман. Ю. М. История и типология русской культуры. СПб., 2002.

23. Марисина И. М. Россия - Франция. Век восемнадцатый. М., 1995.

24. Молева Н. М., Белютин Э. М. Педагогическая система в Академии художеств XVIII века. M., 1956.

25. Недошвин Г. А. Шубин Федот Иванович. 1740-1805. [Краткий очерк жизни и деятельности]. М.-Л., «Искусство», 1944.

26. Никольский В. А. История русского искусства. М., 1915.

27. Пекарский П. П. Наука и литература в России при Петре Великом. СПб., 1862.

28. Петинова Е. Ф. Федос Щедрин. Л., «Художник РСФСР», 1977.

29. П Петров В. Н. Михаил Иванович Козловский. М., «Искусство», 1977.

30. Ромм А. Г. Михаил Иванович Козловский. 1753-1802 [Жизнь и творчество русского скульптора]. М.-Л., «Искусство», 1945 .

31. Савинов А. Н. Антон Павлович Лосенко. М.-Л., 1948.

32. Сборник материалов для истории Императорской Санкт-Петербургской академии художеств за 100 лет. Под редакцией Петрова П. Н. СПб., 1864-1866.

33. Сивков К. В. Путешествия русских людей за границу в XVIII веке. СПб., 1914.

34. Скворцов А. Федор Яковлевич Алексеев. М.-Л., «Искусство», 1945.

35. Tрубников А. Пенсионеры академии художеств в XVIII веке // Старые годы. Июль-сентябрь, 1907.

36. Ухтомский С. Федот Иванович Шубин. Л., 1928.

37. Федоров-Давыдов А. А. Русский пейзаж. XVIII- начало XIX века. M., 1953.

38. Эрнст С. Р. Лосенко. СПб., 1914.

39. Яремич С. П. Русская академическая художественная школа в XVIII веке. М.-Л., 1934.

\section{References (transliteration):}

1. Ajnalov D. V. Istorija russkoj zhivopisi ot XVI do XIX veka. SPb., 1909.

2. Alpatov M.V. Ivan Petrovich Martos. M.-L., Iskusstvo., 1947.

3. Androsova M. I. Fedor Alekseev. 1753-1824. L., 1979.

4. Bezobrazov P. V. O snoshenijah Rossii s Franciej. M., Universitetskaja tipografija, 1892.

5. Verman K. Istorija vseh vremen i narodov. M., 2000.

6. Gavrilova E. I. Anton Pavlovich Losenko. L., 1977.

7. Golubev S. N. Trudy i dni arhitektora Vasilija Bazhenova. M., 1937.

8. Gofman I. M. Ivan Petrovich Martos. L., Hudozhnik RSFSR, 1970.

9. Grabar' I. Je. Istorija russkogo iskusstva. M., Izd-vo I. Knebelja, 1910-1913.

10. Evangulova O. S. Russkoe hudozhestvennoe soznanie XVIII veka i iskusstvo zapadnoevropejskih shkol. M., «Pamjatniki istoricheskoj mysli», 2007.

11. Zhidkov G. V. Obraz Shubina. K 140-letiju so dnja smerti velikogo russkogo skul'ptora. [1805-1945]. M., 1946.

12. Zgura V. V. problemy i pamjatniki, svjazannye s V.I. Bazhenovym. Kazan'., 1928.

13. Ikonnikov V. S. Snoshenija Rossii s Franciej (XVI-XVIII vv.). Istoricheskij ocherk. M., 1893. 
14. Isakov S. K. Fedot Shubin. M., «Iskusstvo», 1938.

15. Kaganovich A. L. Anton Losenko i russkoe iskusstvo XVIII stoletija. M., 1963.

16. Kaganovich A. L. Shhedrin Feodosij Fedorovich. 1751-1825. M., «Iskusstvo», 1953.

17. Kizevetter A. A. Petr Velikij za granicej. M., 1910.

18. Knjaz'kov S. A. Petr Velikij i ego sovremenniki za granicej. Pg., 1915.

19. Kovalenskaja N. N. Martos. M.-L., Iskusstvo, 1938.

20. Kovalenskaja N. N. Russkij klassicizm. Zhivopis', skul'ptura, grafika. M., «Iskusstvo», 1964.

21. Lazareva O. P. Russkij skul'ptor Fedot Shubin. M., «Iskusstvo», 1965.

22. Lotman. Ju. M. Istorija i tipologija russkoj kul'tury. SPb., 2002.

23. Marisina I. M. Rossija - Francija. Vek vosemnadcatyj. M., 1995.

24. Moleva N. M., Beljutin Je. M. Pedagogicheskaja sistema v Akademii hudozhestv XVIII veka. M., 1956.

25. Nedoshvin G. A. Shubin Fedot Ivanovich. 1740-1805. [Kratkij ocherk zhizni i dejatel'nosti]. M.-L., «Iskusstvo», 1944 .

26. Nikol'skij V. A. Istorija russkogo iskusstva. M., 1915 .

27. Pekarskij P. P. Nauka i literatura v Rossii pri Petre Velikom. SPb., 1862.

28. Petinova E. F. Fedos Shhedrin. L., «Hudozhnik RSFSR», 1977.

29. Petrov V. N. Mihail Ivanovich Kozlovskij. M., «Iskusstvo», 1977.

30. Romm A. G. Mihail Ivanovich Kozlovskij. 1753-1802 [Zhizn' i tvorchestvo russkogo skul'ptora]. M.-L., «Iskusstvo», 1945.

31. Savinov A. N. Anton Pavlovich Losenko. M.-L., 1948.

32. Sbornik materialov dlja istorii Imperatorskoj Sankt-Peterburgskoj akademii hudozhestv za 100 let. Pod redakciej Petrova P. N. SPb., 1864-1866.

33. Sivkov K. V. Puteshestvija russkih ljudej za granicu v XVIII veke. SPb., 1914.

34. Skvorcov A. Fedor Jakovlevich Alekseev. M.-L., «Iskusstvo», 1945.

35. Trubnikov A. Pensionery akademii hudozhestv v XVIII veke // Starye gody. Ijul'-sentjabr', 1907.

36. Uhtomskij S. Fedot Ivanovich Shubin. L., 1928.

37. Fedorov-Davydov A. A. Russkij pejzazh. XVIII- nachalo XIX veka. M., 1953.

38. Jernst S. R. Losenko. SPb., 1914.

39. Jaremich S. P. Russkaja akademicheskaja hudozhestvennaja shkola v XVIII veke. M.-L., 1934. 